Article

\title{
Cloning, Expression, and Characterization of a Novel Thermostable and Alkaline-stable Esterase from Stenotrophomonas maltophilia OUC_Est10 Catalytically Active in Organic Solvents
}

\author{
Xinwei Gao ${ }^{1}$, Xiangzhao Mao ${ }^{1,2}{ }^{\mathbb{D}}$, Ping Lu ${ }^{1}$, Francesco Secundo ${ }^{3}\left(\mathbb{D}\right.$, Changhu Xue $^{1,2}$ \\ and Jianan Sun ${ }^{1, *}$ \\ 1 College of Food Science and Engineering, Ocean University of China, Qingdao 266003, China; \\ xinweigaoouc@163.com (X.G.); xzhmao@ouc.edu.cn (X.M.); luping190425@163.com (P.L.); \\ xuech@ouc.edu.cn (C.X.) \\ 2 Laboratory for Marine Drugs and Bioproducts of Qingdao National Laboratory for Marine Science and \\ Technology, Qingdao 266237, China \\ 3 Istituto di Chimica del Riconoscimento Molecolare, CNR, v. Mario Bianco 9, Milan 20131, Italy; \\ francesco.secundo@icrm.cnr.it \\ * Correspondence: sunjianan@ouc.edu.cn; Tel.: +86-532-82031360
}

Received: 22 March 2019; Accepted: 27 April 2019; Published: 29 April 2019

\begin{abstract}
A thermostable and alkaline-stable novel esterase (Est7) was identified through the whole genome sequencing of Stenotrophomonas maltophilia OUC_Est10. The open reading frame of this gene encoded 617 amino acid residues. After heterologous expression in Escherichia coli BL21 (DE3), the purified Est7 was separated as a single protein and presented a molecular mass of $70.6 \mathrm{kDa}$. Multiple sequence alignment indicated that Est7 had a typical catalytic triad (Ser-Asp-His) and the conserved sequence (GDSL) typical of the family II lipid hydrolase proteins. Est7 showed good stability in alkaline buffers, especially in Tris- $\mathrm{HCl}$ buffer at $\mathrm{pH} 9.0$ (residual activity $93.8 \%$ after $96 \mathrm{~h}$ at $4{ }^{\circ} \mathrm{C}$ ) and in the medium temperature conditions (residual activity $70.2 \%$ after $96 \mathrm{~h}$ at $45^{\circ} \mathrm{C}$ and $\mathrm{pH}$ 8.0). The enzyme also retained higher stability toward several hydrophilic and hydrophobic organic solvents (e.g., after incubation in 100\% acetonitrile or in n-hexane the enzyme retained about $97 \%$ and $84 \%$ of the activity in the absence of organic solvent, respectively). Furthermore, Est 7 could catalyze the transesterification reaction of vinylacetate with 2-phenylethanol and cis-3-hexen-1-ol to their corresponding acetate esters in petroleum ether or tert-butyl methyl ether. These results indicate Est7 as a promising biocatalyst for applications of Est7 in non-aqueous media.
\end{abstract}

Keywords: thermostable and alkaline-stable esterase; characterization; transesterification; organic solvents; Stenotrophomonas maltophilia

\section{Introduction}

Esterases (EC 3.1.1.1) can catalyze the hydrolysis or the synthesis of glycerides. Contrary to lipases they have higher substrate specificity toward short chain length glycerides (e.g., carbon chain length <10) [1-4]. Analogously to lipases, apart from the hydrolysis of ester bonds in aqueous systems, esterases can catalyze interesterification, transesterification, esterification, and aminolysis reactions in non-aqueous media (e.g., organic solvents) [5-8].

Esterases usually have high chemical selectivity, regioselectivity, stereospecificity, and stability in organic solvents. They do not need coenzymes and cofactors and are active under mild reaction conditions, which is a prerequisite to obtain fewer by-products in synthetic reactions, thus, making this class of enzymes interesting for organic synthesis purposes at the industrial level [9-11]. 
With the development of biotechnologies, esterases have been widely used in medicine, food, fine chemicals, and biodiesel industries due to their excellent biological properties [12-14]. However, their use in industrial processes has many restrictions under prolonged catalytic reaction conditions or in the presence of organic solvents. Therefore, the identification and characterization of new enzymes with enhanced thermal and $\mathrm{pH}$ stability, and catalytically active and stable in neat organic solvents or in a water-organic solvent mixture, is crucial for industrial applications.

Biocatalysis in organic solvents is a special and practical technique that can increase the number of enzyme applications in organic synthesis, food-related conversions, and analysis [15,16]. In particular, this technique has become the goal of many research activities, allowing to expand the potential of enzymes and develop successful application at the industrial level [17,18]. By changing the organic solvents in the reaction medium, the substrate specificity, the regio- and enantioselectivity of a given enzyme can also be controlled [19-21].

In general, enzymes produced by microorganisms are more widely applicable than those obtained from animals and plants thanks to their lower production cost. Therefore, the increasing demand for novel biocatalysts has led to the development of new methods for screening new genes, such as genome sequencing. Thus, it is possible to obtain more information about lipolytic enzymes sequence by performing whole genome sequencing of known active strains, which is more intuitive and rapid than to screen the lipolytic activity in different strains. Stenotrophomonas maltophilia OUC_Est10 is a gram-negative bacterium that has been shown to secrete esterases and lipases [22]. Herein, we aimed at the heterologous expression in E. coli of the highly active lipolytic enzymes identified in the whole genome of strain S. maltophilia OUC_Est10 [23].

\section{Results and Discussion}

\subsection{Esterase Gene Est7 Sequence and Protein Structure Analysis}

Based on the whole genome sequencing of S. maltophilia OUC_Est10, the analysis and comparison showed that the genome was rich in lipolytic enzyme genes. The nucleotide sequence of the gene of est7 has been submitted to the GenBank database with the accession number MH253883.

By phylogenetic analysis, Est7 was assigned to the lipolytic enzyme family II (Figure 1a). This classification was also confirmed through the analysis of the enzyme structure by the SMART website (URL: http://smart.embl.de/), which showed that the sequence from the 1st to the 26th amino acid residue (MLLSKRPIRSLMAAAIALAAVPAMAG) was a signal peptide typically observed for the lipolytic enzyme family II (Figure 1c). Multiple sequence alignment indicated that Est7 had a typical catalytic triad (Ser-Asp-His) and the conserved sequence (GDSL) typical of the family II lipid hydrolase proteins (Figure 1b).

\subsection{Heterologous Expression and Purification of Est7}

Before heterologous expression in E. coli, esterase gene est7 was inserted into three different plasmids (pET-32a $(+)$, pET-28a $(+)$ or pET-21a (+)). Determination of esterase activity indicated that these three vectors could be used for the expression of Est7. By comparing their enzyme activities, pET-32a (+) was used for further research for its high expression level (data not shown). The purified Est7 was consistent with the predicted molecular mass $(70.6 \mathrm{kDa})$ through sodium dodecyl sulfate polyacrylamide gel electrophoresis sodium dodecyl sulfate-polyacrylamide gel electrophoresis (SDS-PAGE) analysis (Figure 2). There was negligible enzyme activity in the pellet of Est7 cell lysate. The protein concentration of purified Est7 and supernatant of centrifuged Est7 cell lysate were $1.29 \mathrm{mg} \mathrm{mL}^{-1}$ and $3.36 \mathrm{mg} \mathrm{mL}^{-1}$, respectively. The yield of purified Est7 per mL of bacterial culture was $0.29 \mathrm{mg}$, and the specific activity of purified Est7 toward $p$-nitrophenyl butyrate was $69 \mathrm{U} \mathrm{mg}^{-1}$. 
a
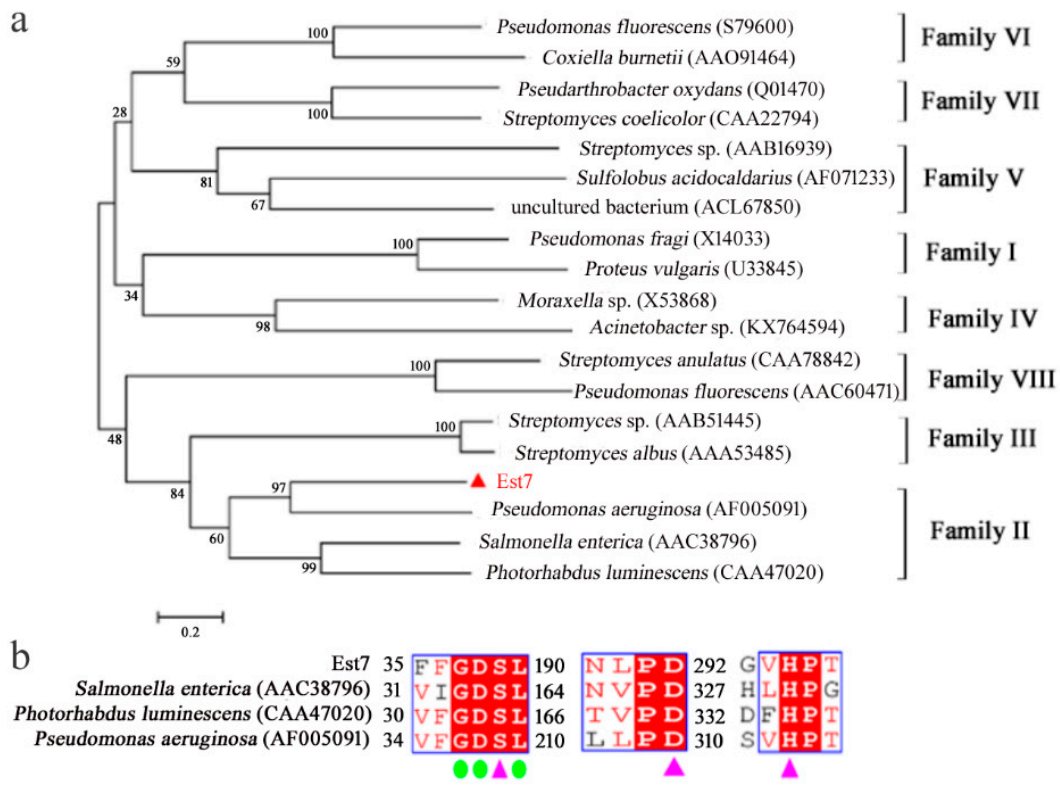

c

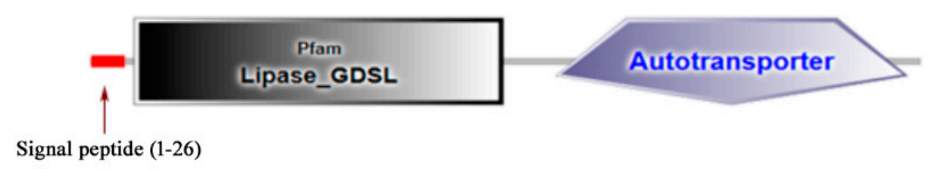

Figure 1. Bioinformatic analysis of Est7. (a) Neighbor-joining phylogenetic tree. Est7 is shown as red triangles. (b) Multiple sequence alignments of Est7 and other lipolytic enzymes belonging to the family II. The typical motif is indicated using green circles, and the catalytic triad (Ser, Asp, His) is emphasized with pink triangles. (c) Analysis of Est7 protein structure.

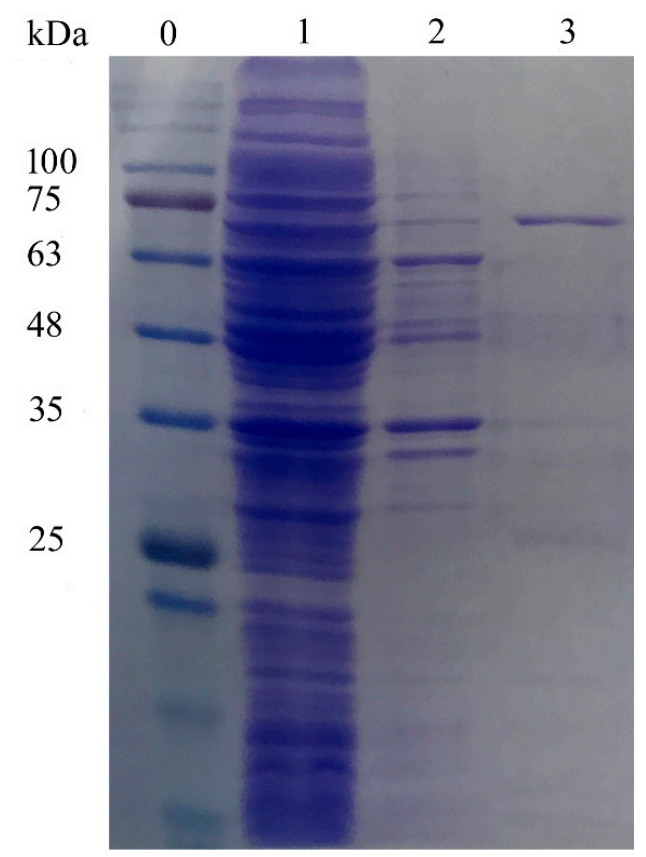

Figure 2. SDS-PAGE analysis of Est7. Lane 0, marker; Lane 1, supernatant of centrifuged Est7 cell lysate; Lane 2, pellet of Est7 cell lysate; Lane 3, purified Est7.

\subsection{Enzyme Characterization of Purified Esterase Est7}

Substrate preference for Est7 was determined with $p$ NP esters with different acyl chain lengths. In Figure 3a it can be observed that Est7 had a relatively high activity with esters with carbon chain 
length $<10$. In particular, Est7 displayed the highest activity toward $p$ NP caproate ( $p$ NPC6), and the lowest activity was observed for $p$ NP palmitate ( $p$ NPC16). This result indicates that Est7 is an esterase that preferentially catalyzed the hydrolysis of short carbon chain length [11,24].

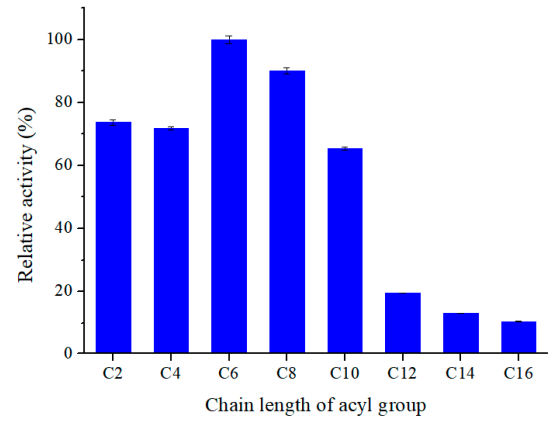

$\mathrm{c}$

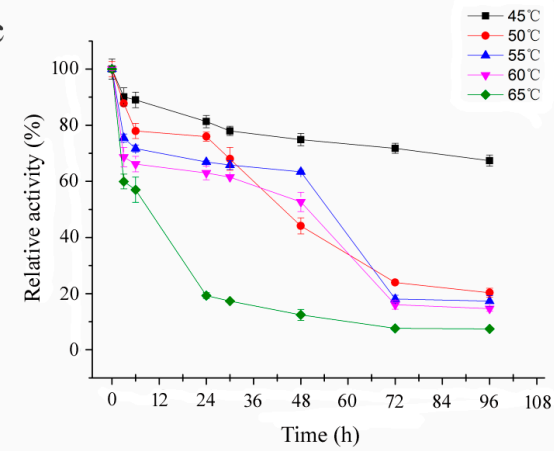

e

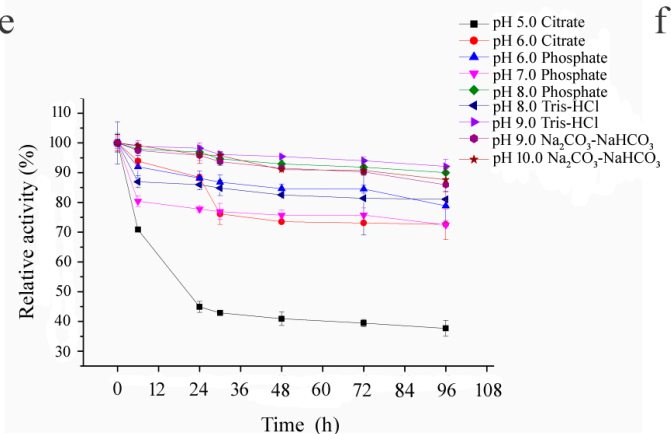

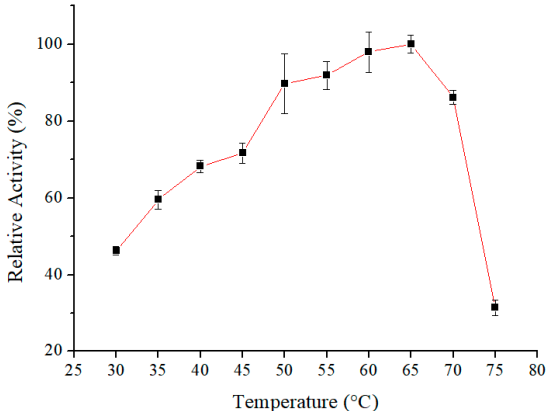

d
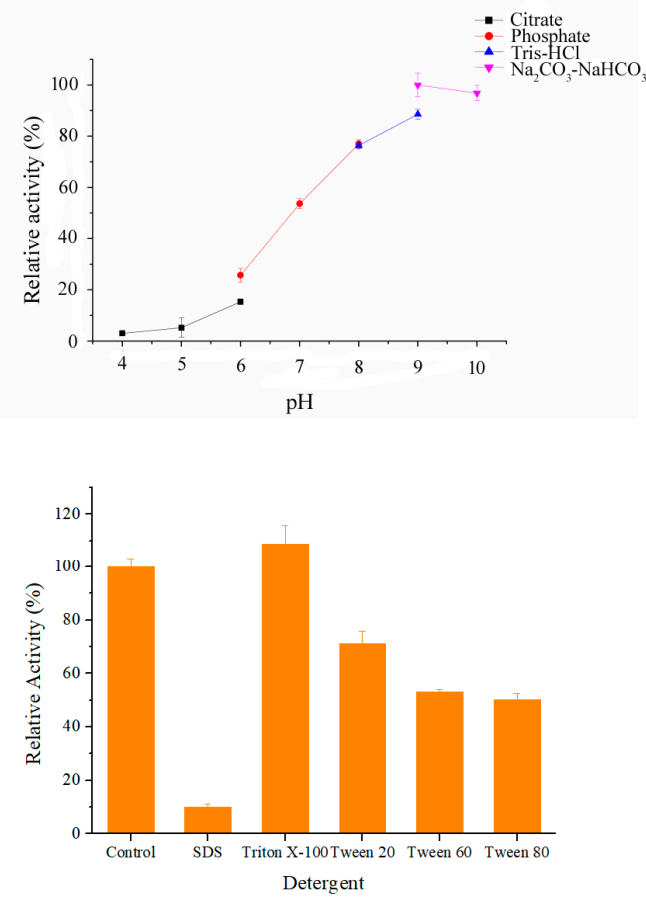

Figure 3. Characterization of Est7. Substrate specificity of Est7 on various $p$ NP esters (a). Effect of temperature on Est7 activity (b). Residual activity of Est7 after incubation in $0.1 \mathrm{M}$ Tris-HCl buffer, $\mathrm{pH} 8.0$, at $45,50,55,60$, or $65^{\circ} \mathrm{C}$ for various durations (c). Effect of $\mathrm{pH}$ on Est7 stability. The buffers used were citrate $(\boldsymbol{\bullet})$, phosphate $(\bullet)$, Tris- $\mathrm{HCl}(\boldsymbol{\Delta})$, and $\mathrm{Na}_{2} \mathrm{CO}_{3}-\mathrm{NaHCO}_{3}(\boldsymbol{v})$. The activity value obtained at pH 9, was considered 100\% (d). Relative activity of Est7, measured after incubation up to $96 \mathrm{~h}$ in different $0.1 \mathrm{M}$ buffers and at different $\mathrm{pHs}$. The activity at time 0 for the different $\mathrm{pH}$ values was considered $100 \%$ (e). Effects of surfactants (0.5\%) on Est7 activity, the reaction without surfactant addition (control) was defined as $100 \%$ (f). Except when differently specified $p$-NP butyrate was used as the substrate (see Materials and Methods, Section 3.4 for experimental details).

Concerning the effect of temperature on Est7 activity, the activity of Est7 increased up to $65^{\circ} \mathrm{C}$ and then declined (Figure $3 b$ ). Interestingly, the optimal temperature for the activity of this enzyme was higher than we found for Est3-14 $\left(60^{\circ} \mathrm{C}\right)$, recently isolated and purified [25]. Therefore, Est7 might be more suitable than this latter enzyme for applications at high-temperature conditions.

The activity of Est7 after incubation at $45{ }^{\circ} \mathrm{C}$ for 96 hours was $70.2 \%$ of that of the control. At $55^{\circ} \mathrm{C}$ and $60{ }^{\circ} \mathrm{C}$, after 48 hours of incubation, the enzyme retained more than $60 \%$ of its original activity. However, the residual activity decreased to $20 \%$ of the original activity within $24 \mathrm{~h}$ at $65{ }^{\circ} \mathrm{C}$ 
(Figure 3c). Based on these data, Est7 appears a mesophilic enzyme that maintains activity at medium and high temperatures.

As shown in Figure 3d, Est7 had relatively high enzyme activities under alkaline conditions and was $\mathrm{pH}$-sensitive, with an optimal activity at $\mathrm{pH} 9.0$ in $\mathrm{Na}_{2} \mathrm{CO}_{3}-\mathrm{NaHCO}_{3}$ buffer and inactivation at $\mathrm{pH}<5.0$.

The $\mathrm{pH}$ stability of the Est7 was determined by measuring the residual activity after incubation for different times $\left(4{ }^{\circ} \mathrm{C}\right.$, up to $96 \mathrm{~h}$ ) in different $\mathrm{pH}$ value buffers ( $\mathrm{pH}$ 5.0-10.0). As shown in Figure $3 \mathrm{e}$ the residual activity of Est7 after $96 \mathrm{~h}$ in Tris- $\mathrm{HCl}$ buffer, $\mathrm{pH}$ 9.0, only slightly decreased $(93.6 \%$ of the initial activity). This result was similar to that obtained with esterase Est3-14 (residual activity $94 \%, 4{ }^{\circ} \mathrm{C}, \mathrm{pH} 8.0$, and $36 \mathrm{~h}$ ) reported by Lu et al. [25]. Furthermore, at $\mathrm{pH} 8.0$ and 10.0, the residual activity of Est7 was higher than $85 \%$, indicating that Est7 had good alkali resistance, analogously to EST4 $\left(40{ }^{\circ} \mathrm{C}\right)$ described by Gao et al. [8]. However, in acidic conditions, beyond citrate buffer at $\mathrm{pH} 5.0$ where the residual enzyme activity decreased to about $40 \%$ of its initial activity, the residual enzyme activity of Est7 was higher than $70 \%$ at $\mathrm{pH}$ 6.0, indicating a good stability also at acidic $\mathrm{pH}$ values.

Different surfactants (tested at $0.5 \% v / v$ concentration) were added to the reaction system to study their effect on the esterase activity of Est7. As shown in Figure 3f, Triton X-100 had a slight promotion effect on enzyme activity (114.8\%). Tween 80, Tween 60, Tween 20, and SDS all had an inhibitory effect on enzyme activity. SDS, an anionic surfactant, could destroy the non-covalent bonds between enzyme molecules, and change the conformation of the enzyme. It had a strong inhibitory effect on the esterase activity of Est7.

The effect of metal ions on the activity of Est7 was determined by adding different concentrations of metal ions to the reaction system. The results are shown in Table $1 . \mathrm{K}^{+}$and $\mathrm{Ca}^{2+}$ had a promoting role on the esterase activity of Est7, especially at when used at $1 \mathrm{mM}$ concentration. In particular, the addition of $1 \mathrm{mM} \mathrm{K}^{+}$increased enzyme activity up to $150 \%$ of the activity in the absence of metal ions. On the contrary, the addition of $10 \mathrm{mM} \mathrm{Cu}^{2+}, \mathrm{Mg}^{2+}, \mathrm{Fe}^{3+}$ or $\mathrm{Co}^{2+}$ decreased the activity 15 to $45 \%$ (the inhibitory effect was most pronounced with $\mathrm{Fe}^{3+}$ and enzyme activity decreased to $55 \%$ of the control activity). The addition $1 \mathrm{mM}$ of $\mathrm{Cu}^{2+}, \mathrm{Ni}^{2+}, \mathrm{Zn}^{2+}, \mathrm{Mg}^{2+}, \mathrm{Fe}^{3+}$ or ethylenediaminetetraacetic acid disodium salt $\left(\mathrm{Na}_{2}\right.$-EDTA) had little effect on the esterase activity of Est7.

Table 1. Effect of $\mathrm{Na}_{2}$-EDTA and metal ions on Est7 activity.

\begin{tabular}{ccc}
\hline \multirow{2}{*}{ Ion } & \multicolumn{2}{c}{ Relative Activity (\%) ${ }^{\mathbf{a}}$} \\
\cline { 2 - 3 } & $\mathbf{1} \mathbf{~} \mathbf{M}$ & $\mathbf{1 0} \mathbf{~} \mathbf{M}$ \\
\hline Control & $100 \pm 2.8$ & $100 \pm 1.2$ \\
$\mathrm{Na}_{2}$-EDTA & $96.7 \pm 1.5$ & $85.3 \pm 2.1$ \\
$\mathrm{Co}^{2+}$ & $78.1 \pm 1.7$ & $67.6 \pm 2.8$ \\
$\mathrm{~K}^{+}$ & $150.2 \pm 2.1$ & $112.2 \pm 2.8$ \\
$\mathrm{Fe}^{3+}$ & $92.3 \pm 3.2$ & $55.1 \pm 2.8$ \\
$\mathrm{Ca}^{2+}$ & $121.3 \pm 1.8$ & $109.2 \pm 1.7$ \\
$\mathrm{Mg}^{2+}$ & $98.7 \pm 2.3$ & $76.5 \pm 2.7$ \\
$\mathrm{Zn}^{2+}$ & $98.5 \pm 2.3$ & $87.5 \pm 1.2$ \\
$\mathrm{Ni}^{2+}$ & $95.7 \pm 1.4$ & $85.1 \pm 0.6$ \\
$\mathrm{Cu}^{2+}$ & $93.8 \pm 2.4$ & $56.6 \pm 2.7$ \\
\hline
\end{tabular}

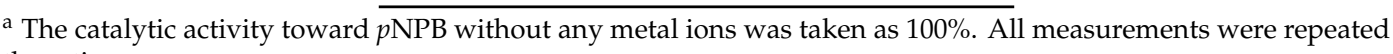
three times.

Organic solvents are usually added to the reaction medium in biocatalyzed reaction to facilitate the solubilization and hydrolysis of hydrophobic substrates. However, the addition of organic solvent can affect enzyme activity and the final yield of the reaction. In particular, water-miscible organic solvents generally deprived the enzyme of the water molecules necessary for its structure and activity, resulting in the inactivation of the enzyme. Therefore, the effect of different organic solvents on Est7 activity was examined [26], and results are shown in Table 2. At a concentration of organic solvent 
of $25 \%(v / v)$, Est7 maintained good activity ( $>70 \%$ of the initial value) in all cases tested. With the increase of concentration to $50 \%(v / v)$, the enzyme activity of Est7 showed a declining trend, but when the concentration of hydrophilic organic solvent was increased to $100 \%(v / v)$ (neat organic solvent), the enzyme activity of Est7 improved. After incubation in pure acetonitrile solvent, the enzyme activity of Est7 was $97.2 \%$ of that just solubilized in buffer, without any organic solvent (control), whereas the residual enzyme activity was $64.7 \%$ after incubation in $50 \%(v / v)$ acetonitrile solvent. This result could be explained considering that in water-organic solvents mixtures protein structural unfolding can occur more easily than in neat organic solvents, as observed with different enzymes [27-29]. For the same reason and similar to other hydrolases, Est7 was stable also in hydrophobic organic solvents. After incubation in $100 \%$ n-hexane, Est7 retained $83.8 \%$ of the activity in the absence of organic solvent, which indicated that Est7 had good stability in both hydrophilic and hydrophobic organic solvents. In particular, compared with other reports, Est7 showed higher stability than rEstSL3 [30] and LipBA45 [31] in organic solvents. These features are good prerequisites for the application of this enzyme in biocatalytic reactions.

Table 2. Effects of organic solvents on Est7 activity.

\begin{tabular}{ccccc}
\hline \multirow{2}{*}{ Organic Solvents } & $\log \boldsymbol{P}^{\mathbf{a}}$ & \multicolumn{3}{c}{ Residual Activity (\%) } \\
\cline { 3 - 5 } & & $\mathbf{2 5}^{\mathbf{c}}$ & $\mathbf{5 0}^{\mathbf{c}}$ & $\mathbf{1 0 0}^{\mathbf{c}}$ \\
\hline Control & & $100 \pm 3.4$ & $100 \pm 2.1$ & $100 \pm 3.2$ \\
DMSO & -1.3 & $76.6 \pm 1.8$ & $56.9 \pm 2.7$ & $32.1 \pm 0.9$ \\
Methanol & -0.76 & $93.6 \pm 4.3$ & $70.7 \pm 1.2$ & $38.8 \pm 1.7$ \\
Ethanol & -0.24 & $92.38 \pm 3.5$ & $71.3 \pm 0.8$ & $55.3 \pm 4.1$ \\
Acetone & -0.23 & $88.4 \pm 1.9$ & $66.9 \pm 3.2$ & $80.5 \pm 3.3$ \\
Acetonitrile & -0.15 & $90.2 \pm 0.3$ & $64.7 \pm 2.1$ & $97.2 \pm 0.2$ \\
Isopropyl alcohol $_{\text {n-Propyl alcohol }}$ & 0.1 & $94.5 \pm 0.6$ & $78.2 \pm 1.2$ & $41.2 \pm 0.4$ \\
Chloroform $^{\mathrm{d}}$ & 0.28 & $97.6 \pm 0.4$ & $86.3 \pm 0.7$ & $50.8 \pm 1.5$ \\
Cyclohexane $^{\mathrm{d}}$ & 2.0 & $70.5 \pm 1.7$ & $60.5 \pm 1.7$ & $24.3 \pm 0.8$ \\
n-Hexane $^{\mathrm{d}}$ & 3.2 & $89.2 \pm 1.4$ & $77.8 \pm 1.4$ & $87.4 \pm 1.6$ \\
Isooctane $^{\mathrm{d}}$ & 3.5 & $75.3 \pm 2.4$ & $66.7 \pm 2.1$ & $83.8 \pm 1.8$ \\
\hline
\end{tabular}

${ }^{\mathrm{a}} \log P$ value is the partition coefficient of an organic solvent between water and $n$-octanol phases. ${ }^{\mathrm{b}}$ After pretreating Est7 for $3 \mathrm{~h}$ in different organic solvents, the remaining enzymatic activity was measured in Tris- $\mathrm{HCl}$ buffer $(100 \mathrm{mM}$, $\mathrm{pH}$ 8.0) by using $p \mathrm{NPB}$ as the test substrate. An enzyme sample incubated in buffer only was used as the measure of $100 \%$ activity. ${ }^{c}$ Organic solvent concentration $(\%, v / v)$ in the enzyme solution. ${ }^{d}$ The percentage of organic solvent is intended as the percentage in the biphasic organic solvent/water system.

\subsection{Catalytic Activity of Esterase Est7 in Organic Solvents}

To further expand the applications of esterase Est7, this enzyme was tested in the transesterification reaction of vinyl acetate with different alcohols (substrate 2-phenylethanol or cis-3-hexen-1-ol) and carried out in pure organic solvents (petroleum ether or tert-butyl methyl ether) as the reaction medium. As shown in Figure 4, comparing the results of Gas chromatography (GC) analysis of the reaction mixture without enzymes and the standard of products, it could be found that Est7 displayed high transesterification activity in the non-aqueous systems, allowing the synthesis of cis-3-hexen-1-yl acetate and 2-phenethyl acetate. Furthermore, quantitative analysis of products was carried out by internal standard method. Under the reaction conditions employed, the concentration of 2-phenethyl acetate and cis-3-hexen-1-yl acetate was $0.192 \mathrm{M}$ and $0.189 \mathrm{M}$, respectively, after $12 \mathrm{~h}$ in tert-butyl methyl ether. The presence in the chromatogram of all the reaction samples of peaks at around 6.1 and $6.7 \mathrm{~min}$ (Figure $4 \mathrm{e}-\mathrm{h}$ ) could be due to the presence of impurities (or their derivatives caused by the reaction with vinyl acetate) present in the enzyme preparation or in the molecular sieves, the extra peaks having the same retention times, independently of the alcohol or of the organic solvent tested. However, these impurities do not interfere with the formation of the acetyl esters, which indicates that Est7 is exploitable in applied biocatalysis in non-aqueous media. 
a
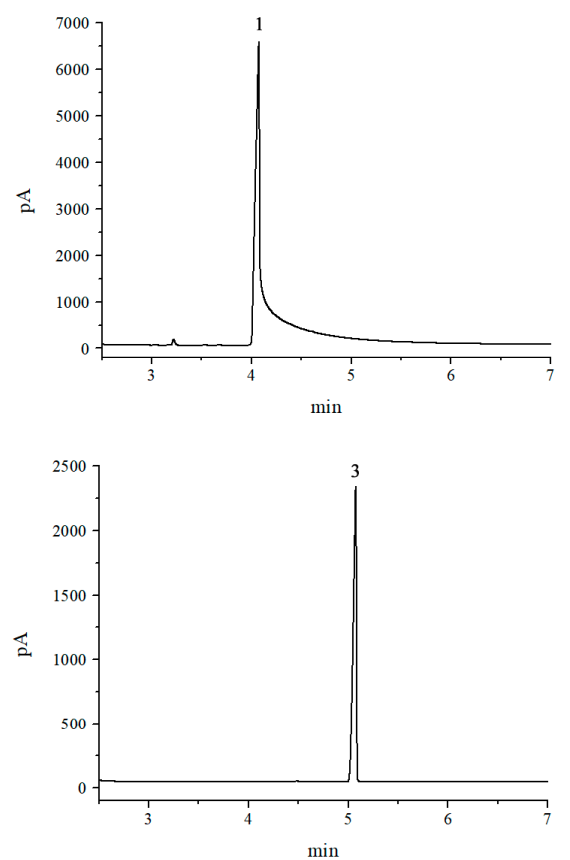

e

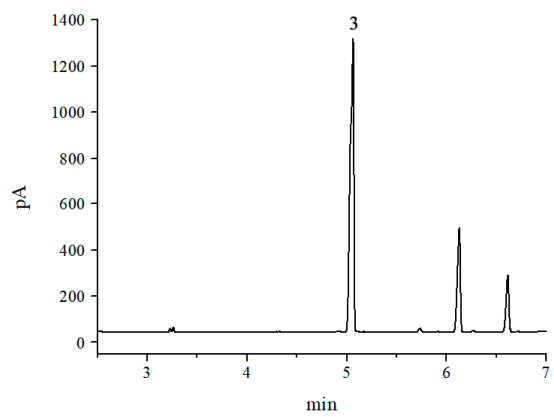

g

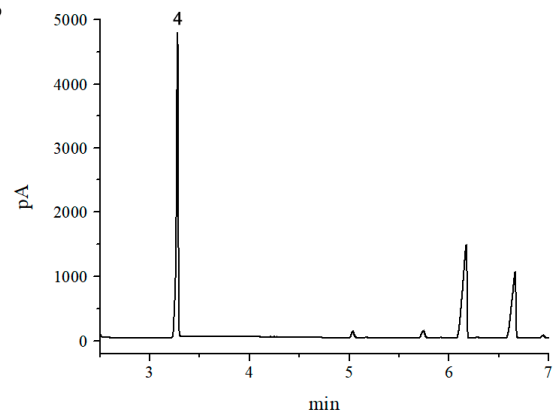

b

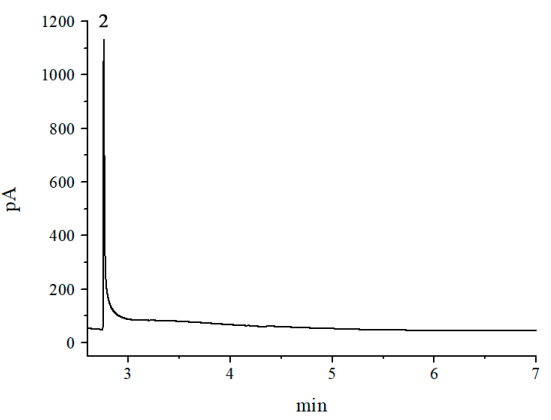

d

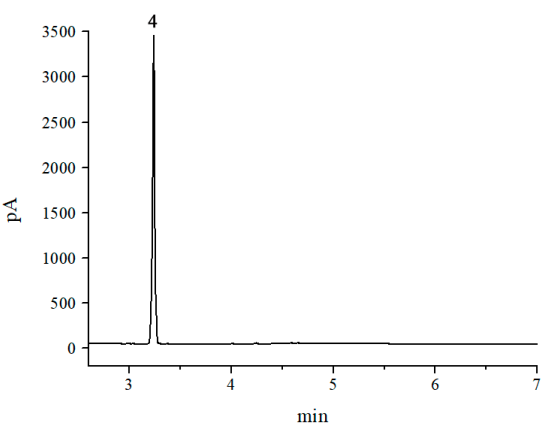

f

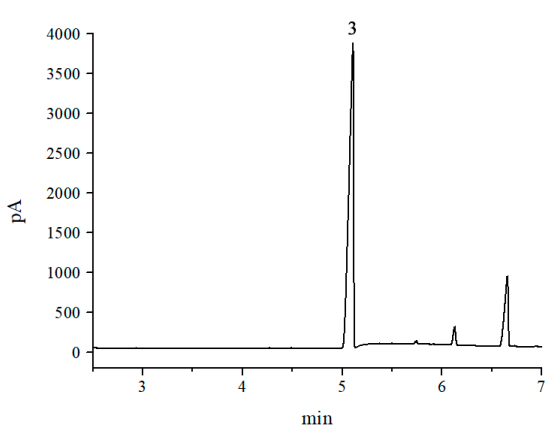

h

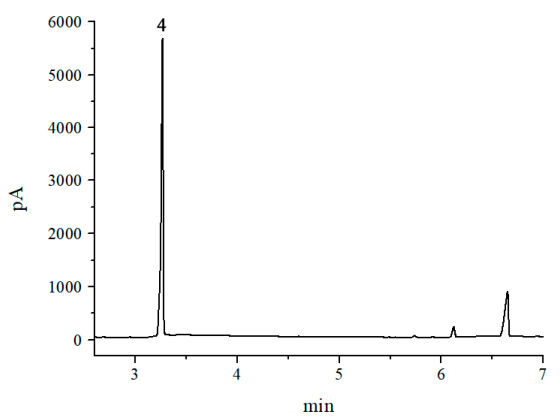

Figure 4. Comparing the results of GC analysis of the reaction medium without Est7 $(\mathbf{a}, \mathbf{b})$ and the standard of product (2-phenethyl acetate, cis-3-hexen-1-yl acetate) (c,d). GC analysis of the transesterification between 2-phenylethanol and vinylacetate to give 2-phenethyl acetate and acetaldehyde in petroleum ether (e) or tert-butyl methyl ether (f) and of the transesterification between cis-3-hexen-1-ol and vinylacetate to give cis-3-hexen-1-yl acetate and acetaldehyde in petroleum ether (g) or tert-butyl methyl ether (h). Peak 1, 2-phenylethanol (retention time 4.1); Peak 2, cis-3-hexen-1-ol (retention time 2.8); Peak 3, 2-phenethyl acetate (retention time 5.1); Peak 4, cis-3-hexen-1-yl acetate (retention time 3.3). In all cases, the reaction time was $12 \mathrm{~h}$. The chromatographic analysis of a sample prepared by mixing volumes (1:1) of the reaction sample and of the standard sample of the expected ester produced a chromatogram with only one peak at the retention time corresponding to that of the ester (data not shown). 


\section{Materials and Methods}

\subsection{Materials}

Restriction enzymes (BamHI, EcoRI, and HindIII) and T4 DNA ligase were obtained from Thermo Fisher Scientific (US). E. coli DH5 $\alpha$ and BL21 (DE3) competent cells were from Tiangen Biochemical Technology Co., Ltd. (Beijing, China). Vinyl acetate (purity percentage $\geq 99.5 \%$ ) was obtained from Macklin Biochemical Technology Co., Ltd. (Shanghai, China). The $p$-nitrophenol ( $p$ NP) and its esters were purchased from Sigma-Aldrich (St. Louis, MO, USA). Molecular sieves were purchased from Beijing Solarbio Science and Technology Co., Ltd. (Beijing, China) and all other reagents used were of analytical grade unless otherwise specific instructions.

\subsection{Bacterial Strains, Plasmids, and Sequence Analysis of Lipolytic Genes}

The complete genome sequence of S. maltophilia OUC_Est10 consists of a single chromosome of $4,668,743-b p$ with a CG content of $66.25 \%$ [23]. Sixteen genes corresponding to the predicted lipolytic enzymes were selected for cloning and expression. Among them, the esterase gene est7 ligated to pET-32a (+) had hydrolytic activity on the $p$ NP esters of C4-C16, suggesting its potential for use in the synthesis of long-chain fatty acid glycerides. The nucleotide sequence of esterase gene est7 sequence information was analyzed by the OUC_Est10 full genome annotation information [23]. The length of the esterase gene est7 sequence was $1854 \mathrm{bp}$.

Phylogenetic tree of esterase Est7 and other lipid hydrolase families was analyzed by MEGA 6.0 software according to the classification reported by Arpigny and Jaeger [32]. The expression plasmids used were select pET-28a (+), pET-21a (+), and pET-32a $(+)$, and the recombinant vectors were transformed into $E$. coli BL21 (DE3) to express the active protein.

\subsection{Heterologous Expression and Purification of Esterase Est7}

To heterologously express an esterase Est7 in E. coli, the constructed primers according to the nucleotide sequence of the Est7 were (EcoRI) 5'-CCGGAATTCATGCTGCTCAGCAAACGCC-3' (forward) and Reverse (HindIII) 5'-CCCAAGCTTTTAGAAGCTGCCGCTGAAGTTG-3' (Reverse), where the underlining indicated the restriction sites. After digestion with EcoRI and HindIII, the fragment amplified by PCR was inserted into pET-32a $(+)$, and the recombinant vector was transformed into E. coli BL21 (DE3) for expression. The recombinant strain was grown in lysogeny broth (LB) medium, and cultured in a shaker at $37^{\circ} \mathrm{C}$ until the $\mathrm{OD}_{600}$ reached 0.6 to 0.8 , and then isopropyl- $\beta$-D-1-thiogalactopyranoside (IPTG) was added to a final concentration of $0.1 \mathrm{mM}$ to induce expression at $20^{\circ} \mathrm{C}$ for $20 \mathrm{~h}(200 \mathrm{rpm})$. After $20 \mathrm{~h}$, the fermentations were centrifuged at $4{ }^{\circ} \mathrm{C}$ for $20 \mathrm{~min}$ $(5439 \times g)$, then cells were harvested and disrupted in Tris-HCl buffer (pH 8.0, $100 \mathrm{mM})$ (buffer A) by ultrasonic fragmentation (ultrasound $3 \mathrm{~s}$, interval $5 \mathrm{~s}$, power 200-400 W, 100 cycles). The cell-free extracts were prepared by centrifugation at $4{ }^{\circ} \mathrm{C}$ for $20 \mathrm{~min}(5439 \times \mathrm{g})$, the precipitate was discarded.

The purity of Est7 and the expression level was assayed by SDS-PAGE standard method [33]. The suspension was sonicated, and the supernatant was loaded on a Ni-nitrilotriacetic acid (Ni-NTA) column (1 mL, Qiagen, Hilden, Germany). The Est7 was eluted by gradient elution with buffer A containing different concentrations $(20 \mathrm{mM}-500 \mathrm{mM})$ of imidazole.

\subsection{Enzyme Characterization of Purified Esterase Est7}

The esterase Est7 activity was assayed by a spectrophotometric method using $p$-nitrophenyl butyrate $(p \mathrm{NPB})$ as a substrate and determining the $p$-nitrophenol $(p \mathrm{NP})$ produced at $405 \mathrm{~nm}$. To this end, $20 \mu \mathrm{L}$ of enzyme solution $\left(1.29 \mathrm{mg} \mathrm{mL}^{-1}\right)$ was added to $0.75 \mathrm{~mL}$ of Tris- $\mathrm{HCl}(100 \mathrm{mM}, \mathrm{pH} \mathrm{8.0)}$ buffer containing $20 \mu \mathrm{L}$ of $p$ NPB substrate solution $(20 \mathrm{mM} p \mathrm{NPB}$ dissolved in isopropyl alcohol and dimethyl sulfoxide $(v / v, 3 / 1))$ and the mixture placed in a $37^{\circ} \mathrm{C}$ water bath for $5 \mathrm{~min}$. The reaction was stopped adding SDS (final concentration 1\%), and the absorbance was measured at $405 \mathrm{~nm}$. An esterase 
activity unit (U) is defined as the amount of enzyme required to produce $1 \mu \mathrm{mol}$ of $p \mathrm{NP}$ per minute. Soluble protein content was estimated by the Bradford assay [34].

The substrate specificity of the purified enzyme Est7 was tested by using $p$ NP esters containing different carbon chain length ( $p$ NP acetate (C2, $p$ NPC2), $p$ NP butyrate (C4, $p$ NPC4), $p$ NP caproate (C6, $p$ NPC6), $p$ NP octanoate (C8, $p$ NPC8), $p$ NP decanoate (C10, $p$ NPC10), $p$ NP laurate (C12, $p$ NPC12), $p$ NP myristate (C14, $p$ NPC14), and $p$ NP palmitate (C16, $p$ NPC16).

Effect of temperature on esterase Est7 activity was studied in the range of 30 to $75^{\circ} \mathrm{C}$, in buffer $\mathrm{A}$ and with $p \mathrm{NPB}$ as the substrate. The enzyme activity at the optimum temperature was defined as $100 \%$, and the activity at other temperatures was expressed as a percentage of the highest activity. The thermostability of Est7 was tested by incubating the enzyme in buffer $\mathrm{A}$ at $45^{\circ} \mathrm{C}, 50^{\circ} \mathrm{C}, 55^{\circ} \mathrm{C}$, $60{ }^{\circ} \mathrm{C}$, or $65^{\circ} \mathrm{C}$ for $96 \mathrm{~h}$, respectively.

Effect of $\mathrm{pH}$ on enzyme activity of Est7 was studied using different buffer solutions with different $\mathrm{pH}$ values. The buffers used were: $100 \mathrm{mM}$ citrate buffer for $\mathrm{pH} 4.0-6.0,100 \mathrm{mM}$ phosphate buffer for $\mathrm{pH}$ 6.0-8.0, $100 \mathrm{mM}$ Tris- $\mathrm{HCl}$ buffer solution for $\mathrm{pH}$ 8.0-9.0, $100 \mathrm{mM} \mathrm{Na}{ }_{2} \mathrm{CO}_{3}-\mathrm{NaHCO}_{3}$ buffer for $\mathrm{pH}$ 9.0-10.0. To determine the $\mathrm{pH}$ stability of Est7, the purified Est7 was incubated for $36 \mathrm{~h}$ in different buffers.

Effect of surfactants on the enzyme activity of Est7 activity was evaluated by adding different surfactants (Tween 20, Tween 60 , Tween 80 , and SDS) to a final concentration of $0.5 \%$ in buffer A. The enzyme without the addition of a surfactant was used as the control.

The effect of metal ions on the activity of esterase Est7 was to add metal ions $\left(\mathrm{Co}^{2+}, \mathrm{K}^{+}, \mathrm{Fe}^{3+}\right.$, $\mathrm{Ca}^{2+}, \mathrm{Mg}^{2+}, \mathrm{Zn}^{2+}, \mathrm{Ni}^{2+}$ or $\mathrm{Cu}^{2+}$ ) and $\mathrm{Na}_{2}$-EDTA to the buffer $\mathrm{A}$ at a final concentration of $1 \mathrm{mM}$ and $10 \mathrm{mM}$. The enzyme activity of the sample in which metal ions and $\mathrm{Na}_{2}$-EDTA were not added was defined as $100 \%$.

The effect of organic solvents on Est7 enzyme activity was studied mixing dimethyl sulfoxide (DMSO), methanol, ethanol, acetone, acetonitrile, isopropyl alcohol, n-propyl alcohol, chloroform, cyclohexane, $\mathrm{n}$-hexane or isooctane with the enzyme solution ( $\mathrm{pH}$ 8.0, $100 \mathrm{mM}$ Tris- $\mathrm{HCl}$ buffer solution, $1.29 \mathrm{mg} \mathrm{mL}^{-1}$ ) at a final concentration of $25 \%, 50 \%$ or $100 \%$. The mixture was shaken at $30^{\circ} \mathrm{C}$ for $3 \mathrm{~h}$, and then the residual enzyme activity was determined as described above. In the case of hydrophobic organic solvents, the biphasic system (organic solvent/enzyme solution) after the incubation was centrifuged to remove the organic solvent, and the enzyme activity of Est7 was measured under standard conditions. In the case of hydrophilic organic solvent, the mixed solution after the incubation was diluted with buffer A until the concentration of the organic solvent was $5 \%$ to reduce the effect of remaining organic solvents on enzyme activity determination.

\subsection{Esterase Est7 Catalyzed Transesterification}

To study the application of esterase Est7 in synthetic reactions in neat organic solvents, the purified enzyme Est7 was previously frozen at $-80^{\circ} \mathrm{C}$ and then lyophilized. The transesterification between 2-phenylethanol (cis-3-hexen-1-ol) and vinylacetate to give 2-phenethyl acetate (cis-3-hexen-1-yl acetate) and acetaldehyde was used as the model reaction. For the transesterification reaction, $360 \mathrm{U}$ of lyophilized biocatalyst $\left(69 \mathrm{U} \mathrm{mg}^{-1}\right.$ ) was added to $1 \mathrm{~mL}$ of organic solvent (petroleum ether or tert-butyl methyl ether) containing $0.2 \mathrm{M}$ alcohol (substrate 2-phenylethanol or cis-3-hexen-1-ol) and $0.6 \mathrm{M}$ vinyl acetate and adding molecular sieves $(80 \mathrm{mg}$ of molecular sieve per $\mathrm{mL}$ of reaction) to ensure dry conditions. The reaction mixture was incubated at $37^{\circ} \mathrm{C}$ for $12 \mathrm{~h}$ in a rotary shaker $(180 \mathrm{rpm})$. At predetermined timepoints, aliquots were withdrawn from the reaction mixtures and the conversion determined by GC analysis. The reaction mixtures without Est7 was used as the control. A 6890 gas chromatograph (Agilent Technologies, USA) equipped with a flame ionization detector (FID) was used. The stationary phase was an HP-5 capillary column $(30 \mathrm{~m} \times 250 \mu \mathrm{m} \times 0.25 \mu \mathrm{m})$. The mobile phase was nitrogen, and the oven temperature was varied from $120^{\circ} \mathrm{C}$ (initial time $0.5 \mathrm{~min}$ ) to $180^{\circ} \mathrm{C}$ with a heating rate of $10^{\circ} \mathrm{C} \mathrm{min}^{-1}$ [20]. 
The internal standard method was used to quantify the reaction product using n-octanol $\left(2 \mu \mathrm{L} \cdot \mathrm{mL}^{-1}\right.$ in tert-butyl methyl ether) as the internal standard. The internal standard solution was used to prepare a $0.1 \mathrm{M}$ 2-phenethyl acetate or cis-3-hexen-1-yl acetate (standard) solution, and the peak area/moles ratio for the internal standard $\left(A_{s} / m_{s}\right)$ and for the ester $\left(A_{r} / m_{r}\right)$ were determined and used to calculate the ratio.

$$
f=\frac{\frac{A s}{m s}}{\frac{A r}{m r}}
$$

Then the reaction solution containing the internal standard $\left(2 \mu \mathrm{L} \cdot \mathrm{mL}^{-1}\right)$ was injected, and the concentration of products was calculated according to the peak response value of the internal standard as follow:

$$
m i=f \times \frac{A i}{\frac{A s}{m s}}
$$

where $A_{i}$ is the peak area of the product and $A_{s} / m_{S}$ is the peak area/moles ratio for the internal standard determined in the analysis of the reaction sample.

\section{Conclusions}

The identification herein presented of a moderately thermophylic (optimum temperature at $65^{\circ} \mathrm{C}$ ) and alkaline-stable novel esterase (Est7), and confirmed S. maltophilia OUC_Est10 as a source of numerous lipolytic and esterolytic activities. The isolated enzyme also showed a good tolerance toward both hydrophobic and hydrophilic organic solvents. These properties, and the fact that Est7 could catalyze transesterification reaction in pure organic solvents, highlight the exploitability of this enzyme in numerous biotechnological applications including in organic synthesis reactions. Furthermore, the possibility to overexpress Est7 in E. coli BL21 (DE3) made this enzyme particularly interesting for large scale applications. In addition, further improvements of stability and specificity can also be envisaged by enzyme engineering of Est7. Finally, the approach herein followed for the identification of new enzyme activities (e.g., searching new enzyme activity from the whole genome sequence of known active strains) resulted as very promising for the identification of new efficient and versatile enzymes and a more rapid method than screening new enzymes from different strains.

Author Contributions: Data curation, X.G., X.M., P.L., C.X. and J.S.; Funding acquisition, X.M., C.X. and J.S.; Investigation, X.G. and X.M.; Methodology, P.L., F.S. and J.S.; Project administration, X.M. and J.S.; Supervision, J.S.; Writing—original draft, X.G.; Writing—review and editing, discussion of results, X.M. and F.S.

Funding: This work was supported by the National Natural Science Foundation of China (31501516), Major Special Science and Technology Projects in Shandong Province (2016YYSP016), Applied Basic Research Program of Qingdao (16-5-1-18-jch), the Fundamental Research Funds for the Central Universities (NO. 201941002) and Taishan Scholar Project of Shandong Province (NO. tsqn201812020).

Conflicts of Interest: The authors declare no conflict of interest.

\section{References}

1. Ramnath, L.; Sithole, B.; Govinden, R. Identification of lipolytic enzymes isolated from bacteria indigenous to Eucalyptus wood species for application in the pulping industry. Biotechnol. Rep. 2017, 15, 114-124. [CrossRef] [PubMed]

2. Fojan, P.; Jonson, P.H.; Petersen, M.T.N.; Petersen, S.B. What distinguishes an esterase from a lipase: A novel structural approach. Biochimie 2000, 82, 1033-1041. [CrossRef]

3. Khudary, R.; Venkatachalam, R.; Katzer, M.; Elleuche, S.; Antranikian, G. A cold-adapted esterase of a novel marine isolate, Pseudoalteromonas arctica: Gene cloning, enzyme purification and characterization. Extremophiles 2010, 14, 273-285. [CrossRef]

4. Jaeger, K.E.; Ransac, S.; Dijkstra, B.W.; Colson, C.; Van, H.M.; Misset, O. Bacterial lipases. FEMS Microbiol. Rev. 1994, 15, 29-63. [CrossRef] [PubMed] 
5. Ferrer, M.; Bargiela, R.; Martínez-Martínez, M.; Mir, J.; Koch, R.; Golyshina, O.V.; Golyshin, P.N. Biodiversity for biocatalysis: A review of the $\alpha / \beta$-hydrolase fold superfamily of esterases-lipases discovered in metagenomes. Biocatal. Biotransform. 2016, 33, 1-15. [CrossRef]

6. Salihu, A.; Alam, M.Z. Solvent tolerant lipases: A review. Process Biochem. 2015, 50, 86-96. [CrossRef]

7. Persson, M.; Bornscheuer, U.T. Increased stability of an esterase from Bacillus stearothermophilus in ionic liquids as compared to organic solvents. J. Mol. Catal. B Enzym. 2003, 22, 21-27. [CrossRef]

8. Gao, W.; Wu, K.; Chen, L.; Fan, H.; Zhao, Z.; Gao, B.; Wang, H.; Wei, D. A novel esterase from a marine mud metagenomic library for biocatalytic synthesis of short-chain flavor esters. Microb. Cell Fact. 2016, 15, 41. [CrossRef] [PubMed]

9. Alfonso, I.; Gotor, V. Biocatalytic and biomimetic aminolysis reactions: Useful tools for selective transformations on polyfunctional substrates. Chem. Soc. Rev. 2004, 33, 201-209. [CrossRef]

10. Hasan, F.; Shah, A.A.; Hameed, A. Industrial applications of microbial lipases. Enzyme Microb. Technol. 2006, 39, 235-251. [CrossRef]

11. Bornscheuer, U.T. Microbial carboxyl esterases: Classification, properties and application in biocatalysis. FEMS Microbiol. Rev. 2002, 26, 73-81. [CrossRef]

12. Shafqet, M.A.; Brown, T.V.; Sharma, R. Normal lipase drug-induced pancreatitis: A novel finding. Am. J. Emerg. Med. 2015, 33, 476.e5-476.e6. [CrossRef]

13. Fan, Y.; Wang, X.; Zhang, L.; Li, J.; Yang, L.; Gao, P.; Zhou, Z. Lipase-catalyzed synthesis of biodiesel in a hydroxyl-functionalized ionic liquid. Chem. Eng. Res. Des. 2018, 132, 199-207. [CrossRef]

14. Gupta, R.; Gupta, N.; Rathi, P. Bacterial lipases: An overview of production, purification and biochemical properties. Appl. Microbiol. Biotechnol. 2004, 64, 763-781. [CrossRef]

15. Enzymatic Reactions in Organic Media; Koskinen, A.M.P.; Klibanov, A.M. (Eds.) Blackie Academic and Professional: London, UK, 1996. [CrossRef]

16. Mannino, S.; Cosio, M.S.; Wang, J. Determination of peroxide in vegetable oils by an organic-phase enzyme electrode. Anal. Lett. 1994, 27, 299-308. [CrossRef]

17. Secundo, F.; Spadaro, S.; Carrea, G.; Overbeeke, P.L. Optimization of Pseudomonas cepacia lipase preparations for catalysis in organic solvent. Biotechnol. Bioeng. 1999, 62, 554-561. [CrossRef]

18. Secundo, F.; Carrea, G.; Soregaroli, C.; Varinelli, D.; Morrone, R. Activity of different Candida antarctica lipase B formulations in organic solvents. Biotechnol. Bioeng. 2001, 73, 157-163. [CrossRef]

19. Carrea, G.; Ottolina, G.; Riva, S. Role of solvents in the control of enzyme selectivity in organic media. Trends Biotechnol. 1995, 13, 63-70. [CrossRef]

20. Dong, H.; Secundo, F.; Xue, C.; Mao, X. Whole-cell biocatalytic synthesis of cinnamyl acetate with a novel esterase from the DNA library of Acinetobacter haemolyticus. J. Agric. Food Chem. 2017, 65, 2120-2128. [CrossRef]

21. Belafriekh, A.; Secundo, F.; Serra, S.; Djeghaba, Z. Enantioselective enzymatic resolution of racemic alcohols by lipases in green organic solvents. Tetrahedron Asymmetry 2017, 28, 473-478. [CrossRef]

22. Dong, H.; Li, X.; Xue, C.; Mao, X. Astaxanthin preparation by fermentation of esters from Haematococcus pluvialis algal extracts with Stenotrophomonas species. Biotechnol. Prog. 2016, 32, 649-656. [CrossRef]

23. Dong, H.; Rui, J.; Sun, J.; Li, X.; Mao, X. Complete genome sequencing and diversity analysis of lipolytic enzymes in Stenotrophomonas maltophilia OUC_Est10. Acta Microbiol. Sin. 2017, 57, 1716-1721. [CrossRef]

24. Fu, C.; Hu, Y.; Xie, F.; Guo, H.; Ashforth, E.J.; Polyak, S.W.; Zhu, B.; Zhang, L. Molecular cloning and characterization of a new cold-active esterase from a deep-sea metagenomic library. Appl. Microbiol. Biotechnol. 2011, 90, 961-970. [CrossRef] [PubMed]

25. Lu, P.; Gao, X.; Dong, H.; Liu, Z.; Secundo, F.; Xue, C.; Mao, X. Identification of a novel esterase from marine environmental genomic DNA libraries and its application in production of free all-trans-astaxanthin. J. Agric. Food Chem. 2018, 66, 2812-2821. [CrossRef]

26. Laane, C.; Boeren, S.; Vos, K.; Veeger, C. Rules for optimization of biocatalysis in organic solvents. Biotechnol. Bioeng. 2009, 102, 2-8. [CrossRef]

27. Öztürk, D.C.; Kazan, D.; Denizci, A.A.; Grimoldi, D.; Secundo, F.; Erarslan, A. Water miscible mono alcohols effect on the structural conformation of Bacillus clausii, GMBAE 42 serine alkaline protease. J. Mol. Catal. B Enzym. 2010, 64, 184-188. [CrossRef] 
28. Secundo, F.; Fialà, S.; Fraaije, M.W.; De Gonzalo, G.; Meli, M.; Zambianchi, F.; Ottolina, G. Effects of water miscible organic solvents on the activity and conformation of the baeyer-villiger monooxygenases from Thermobifida fusca and Acinetobacter calcoaceticus: A comparative study. Biotechnol. Bioeng. 2011, 108, 491-499. [CrossRef]

29. Zaks, A.; Klibanov, A.M. Enzymatic catalysis in nonaqueous solvents. J. Biol. Chem. 1988, 263, $3194-3201$. [PubMed]

30. Wang, G.; Wang, Q.; Lin, X.; Ng, T.B.; Yan, R.; Lin, J.; Ye, X. A novel cold-adapted and highly salt-tolerant esterase from Alkalibacterium sp. SL3 from the sediment of a soda lake. Sci. Rep. 2016, 6, 19494. [CrossRef] [PubMed]

31. Cai, X.; Ma, J.; Wei, D.Z.; Lin, J.P.; Wei, W. Functional expression of a novel alkaline-adapted lipase of Bacillus amyloliquefaciens from stinky tofu brine and development of immobilized enzyme for biodiesel production. Antonie Van Leeuwenhoek 2014, 106, 1049-1060. [CrossRef]

32. Arpigny, J.L.; Jaeger, K.E. Bacterial lipolytic enzymes: Classification and properties. Biochem. J. 1999, 343, 177-183. [CrossRef] [PubMed]

33. Laemmli, U.K. Cleavage of structural proteins during the assembly of the head of bacteriophage T4. Nature 1970, 227, 680-685. [CrossRef]

34. Bradford, M.M. A rapid and sensitive method for the quantitation of microgram quantities of protein utilizing the principle of protein-dye binding. Anal. Biochem. 1976, 72, 248-254. [CrossRef]

(C) 2019 by the authors. Licensee MDPI, Basel, Switzerland. This article is an open access article distributed under the terms and conditions of the Creative Commons Attribution (CC BY) license (http://creativecommons.org/licenses/by/4.0/). 